\title{
Pyramiding of three bacterial blight resistance genes for broad-spectrum resistance in deepwater rice variety, Jalmagna
}

Sharat Kumar Pradhan*, Deepak Kumar Nayak, Soumya Mohanty, Lambodar Behera, Saumya Ranjan Barik, Elssa Pandit, Srikanta Lenka and Annamalai Anandan

\begin{abstract}
Background: Jalmagna is a popular deepwater rice variety with farmers of India because of its good yield under waterlogged condition. However, the variety is highly susceptible to bacterial blight (BB) disease. The development of resistant cultivars has been the most effective and economical strategy to control the disease under deepwater situation. Three resistance genes ( $x a 5+x a 13+X a 21)$ were transferred from Swarna BB pyramid line, using a marker-assisted backcrossing (MAB) breeding strategy, into the BB-susceptible elite deepwater cultivar, Jalmagna.

Results: Molecular marker integrated backcross breeding program has been employed to transfer three major BB resistance genes (Xa21, xa13 and xa5) into Jalmagna variety. During backcross generations, markers closely linked to the three genes were used to select plants possessing these resistance genes and markers polymorphic between donor and recurrent parent were used to select plants that have maximum contribution from the recurrent parent genome. A selected $\mathrm{BC}_{3} \mathrm{~F}_{1}$ plant was selfed to generate homozygous $\mathrm{BC}_{3} \mathrm{~F}_{2}$ plants with different combinations of $\mathrm{BB}$ resistance genes. The three-gene pyramid and two gene pyramid lines exhibited high levels of resistance against the BB pathogen. Under conditions of BB infection, the three-gene pyramided lines exhibited a significant yield advantage over Jalmagna. The selected pyramided lines showed all agro-morphologic traits of Jalmagna without compromising the yield.

Conclusion: The three major BB resistance genes pyramided lines exhibited high level of resistance and are expected to provide durable resistance under deep water situation where control through chemicals is less effective. High similarity in agro-morphologic traits and absence of antagonistic effects for yield and other characters were observed in the best pyramided lines.
\end{abstract}

Keywords: Deepwater rice; Marker-assisted selection; Bacterial blight gene pyramiding; Broad-spectrum resistance; Foreground selection; Background selection; xa5; xa13; Xa21

\section{Background}

Rice (Oryza sativa L.) is an important food crop that serves as a major carbohydrate source for nearly half of the world's population. In India, it is grown in 43 million hectares accounting for $42 \%$ of food grain production and $55 \%$ of cereal production. To sustain self-sufficiency and to meet food grain requirement of future, India has to produce $135-140$ million tones of rice by 2030 . This has to necessarily meet from less land, less water, less labor and fewer chemicals, constant battle against new

\footnotetext{
* Correspondence: pradhancrri@gmail.com

Crop Improvement Division, Central Rice Research Institute, Cuttack, Odisha
} 753006, India emerging pathogens and pests and possible adverse effects from climate change (Khush 2005). This ecosystem covers around 4 million hectares of which 3 million hectares are under deepwater ecology and 1 million hectare under very deepwater ecology (floating rice).Under deepwater ecology, the crop remains waterlogged for a period of more than a month with more than $50 \mathrm{~cm}$ water depth while in floating type the water depth remains more than one meter. The average productivity of deepwater ecosystem is around $1 \mathrm{t} / \mathrm{ha}$ while floating type is again very low yield. Bacterial leaf blight (BB) caused by Xanthomonas oryzae pv. oryzae (Xoo) is the most important disease of deepwater rice in India. In some areas

\section{空}


of Asia, it can reduce crop yield by up to $50 \%$ (Khush et al. 1989) or even up to $80 \%$ (Singh et al. 1977). It also causes poor quality fodder. This affects photosynthetic areas and reduces the yield drastically and produce partial grain filling and low quality fodder yield.

Although a large number of rice varieties have been released for different agro-ecosystems in India, only a few are widely grown in deep water situations. Rice varieties, Jalmagna and Dinesh are very widely grown in deep water areas of India. Theses varieties are popular among rice farmers and consumers because of its high yield, medium slender grains and excellent cooking and eating qualities. Despite popularity, these varieties are highly susceptible to many pests and diseases including $\mathrm{BB} . \mathrm{BB}$ is the most important disease of deepwater rice in India and has become a major production constraint. In absence of effective chemical or other control agents against the pathogen in deepwater situation, host plant resistance has gained enormous importance in controlling this disease (Devadath 1989). Therefore, host plant resistance offers the most effective, economical and environmentally safe option for management of BB pathogen in deepwater situation (Khush et al. 1989). In other ecology also, development of resistant cultivars carrying resistant genes have been the most effective and economical strategy to control BB disease and no environmental pollutions (Huang et al. 1997; Jena and MacKill 2008; Singh et al. 2001; Sundaram et al. 2008; Rajpurohit et al. 2011; Dokku et al. 2013; Suh et al. 2013). Globally, thirty eight $\mathrm{BB}$ resistance genes have been identified from diverse sources (Bhasin et al. 2012). A number of these resistance genes have been tagged by closely linked molecular markers (Yoshimura et al. 1995; Sonti 1998; Rao et al. 2002; Gu et al. 2008). A few of these genes like $\mathrm{Xa} 4$ have been incorporated widely in many high yielding varieties through conventional breeding (Khush et al. 1989). However, widespread cultivation of varieties with $\mathrm{Xa} 4$ has led to predominance of Xoo races that can overcome this gene (Mew et al. 1992). The deployment of rice cultivars that have multiple $\mathrm{BB}$ resistance genes is expected to lead to more durable resistance.

Pyramiding multiple $\mathrm{R}$ genes in a single line confers wide-spectrum and durable resistance. Tightly linked DNA markers have been developed for several BB resistance genes. The $\mathrm{BB}$ resistance genes, $\mathrm{Xa1}, x a 5$, $x a 13, X a 21, X a 26$ and Xa27 have been cloned and used for breeding program. With the exception of $x a 5$ and $x a 13$, the $\mathrm{BB}$ resistance genes are dominant in nature and the markers developed from the sequencing information of these genes are widely used in MAS (Song et al. 1995; Yoshimura et al. 1998; Gu et al. 2005; Chu et al. 2006a). Using the gene pyramid approach, improved indica rice cultivars with broad spectrum durable
BB resistance have been developed by combining different genes (Huang et al. 1997; Sanchez et al. 2000; Shanti et al. 2001; Singh et al. 2001; Joseph et al. 2004; Pha and Lang 2004; Bharatkumar et al. 2008; Hu et al. 2008; Perez et al. 2008; Sundaram et al. 2008; Rajpurohit et al. 2011; Dokku et al. 2013; Suh et al. 2013). A three-gene combination appeared to be the most effective; with $\mathrm{Xa} 21$ contributing the largest component of resistance. Therefore, incorporation of three BB resistant genes combination was taken up in the popular variety Jalmagna background by integrating markerassisted backcrossing with phenotypic selection for development of pyramiding lines for the handicapped ecology.

\section{Results}

\section{Pyramiding of bacterial blight resistance genes}

The parent polymorphism was detected for the donor (CRMAS 2232-85) and recurrent parent (Jalmagna) with the markers pTA 248, RG 136 and xa5S, R (multiplex) for the genes $\mathrm{Xa} 21, x a 13$ and $x a 5$ respectively (Table 1). The parents were polymorphic with respect to these genes. In addition, the parents were screened with 236 rice microsatellite markers (Table 2) of which 120 were polymorphic and 60 were used for background selection.

Molecular markers were integrated in the backcross breeding programme upto $\mathrm{BC}_{3} \mathrm{~F}_{2}$ generation. During the breeding procedure, foreground selection was practiced from $\mathrm{F}_{1}$ generation till $\mathrm{BC}_{3} \mathrm{~F}_{3}$ generation at each stage to select the plants having resistance alleles of the three target genes and only progenies having the resistance alleles were advanced for the next generation (Figures 1, 2 and 3). Background selection was started from $B_{1} F_{1}$ to $\mathrm{BC}_{3} \mathrm{~F}_{1}$ generation and in each step genotype possessing highest genome content of the recipient parent was selected to hybridize for next backcross. A total of $650 \mathrm{~F}_{1}$ plants were produced and $150 \mathrm{~F}_{1}$ plants were tested for the hybridity and confirmed by their heterozygosity for the resistance gene linked markers of which 143 plants were observed to be true $F_{1} s$. The true $F_{1}$ s were backcrossed using Jalmagna as a recurrent parent. These crossed seeds were raised (360 $\mathrm{BC}_{1} \mathrm{~F}_{1}$ seeds) for further backcrossing with Jalmagna. Ninety three $\mathrm{BC}_{1} \mathrm{~F}_{1}$ plants showed the presence of $\mathrm{Xa21}$ resistance gene specific bands (1000 bp) while 91 plants showed the presence of xa13 resistance gene specific bands (490 bp and $530 \mathrm{bp}$ ). One hundred sixteen $\mathrm{BC}_{1} \mathrm{~F}_{1}$ plants showed the presence of $x a 5$ resistance gene specific bands (160 bp). Based on the amplification of resistance specific bands, $31 \mathrm{BC}_{1} \mathrm{~F}_{1}$ plants showed the presence of $\mathrm{Xa21}$ and $x a 13$ resistance genes while $42 \mathrm{BC}_{1} \mathrm{~F}_{1}$ plants showed the presence of $\mathrm{Xa21}$ and $x a 5$ resistance genes. Forty six $\mathrm{BC}_{1} \mathrm{~F}_{1}$ plants showed the presence of $x a 13$ and $x a 5$ resistance genes. 
Table 1 Markers used for foreground selection of three bacterial blight resistance genes in marker-assisted backcross breeding

\begin{tabular}{|c|c|c|c|c|c|c|c|}
\hline \multirow{2}{*}{$\begin{array}{l}\text { Resistance } \\
\text { gene }\end{array}$} & \multirow{2}{*}{$\begin{array}{l}\text { Chromosome } \\
\text { number }\end{array}$} & \multirow[t]{2}{*}{ Marker } & \multicolumn{2}{|c|}{ Primer sequences used for gene detection } & \multirow[t]{2}{*}{ Expected size (bp) } & \multirow{2}{*}{$\begin{array}{l}\text { Band } \\
\text { type }\end{array}$} & \multirow[t]{2}{*}{ reference } \\
\hline & & & Forward $\left(5^{\prime}-3^{\prime}\right)$ & Reverse $\left(5^{\prime}-3^{\prime}\right)$ & & & \\
\hline \multirow[t]{2}{*}{$x a 5$} & \multirow[t]{2}{*}{5} & xa5S (Multiplex) & GTCTGGAATTTGCTCGCGTTCG & TGGTAAAGTAGATACCTTATCAAACTGGA & \multirow[t]{2}{*}{$410 \mathrm{bp}, 310 \mathrm{bp}, 180 \mathrm{bp}$} & \multirow[t]{2}{*}{ STS } & \multirow[t]{2}{*}{ Sundaram et al. 2011} \\
\hline & & xa5SR/R (Multiplex) & AGCTCGCCATTCAAGTTCTTGAG & TGACTTGGTTCTCCAAGGCTT & & & \\
\hline$x a 13$ & 8 & RG136 & TCCCAGAAAGCTACTACAGC & GCAGACTCCAGTTTGACTTC & $530 \mathrm{bp}, 490 \mathrm{bp}$ & STS & Huang et al. 1997 \\
\hline$x_{a 21}$ & 11 & pTA248 & AGACGCGGAAGGGTGGTTCCCGGA & AGACGCGGTAATCGAAGATGAAA & $1000 \mathrm{bp}$ & STS & Huang et al. 1997 \\
\hline
\end{tabular}


Table 2 Microsatellite markers those are polymorphic between Jalmagna and CRMAS 2232-85

\begin{tabular}{|c|c|c|c|}
\hline Chromosome & $\begin{array}{l}\text { No. of markers } \\
\text { analyzed }\end{array}$ & $\begin{array}{l}\text { Total no. of polymorphic } \\
\text { markers }\end{array}$ & Name of the polymorphic markers \\
\hline 1 & 25 & 11 & $\begin{array}{l}\text { RM23, RM48, RM212, RM272, RM575, RM428, RM488, SSR09, SSR 31, SSR } 60 \\
\text {,SSR } 71\end{array}$ \\
\hline 2 & 25 & 12 & $\begin{array}{l}\text { RM154, RM211, RM233A, RM263, RM475, RM45, RM530,SSR11, SSR 14, SSR } 44 \\
\text {,SSR } 71 \text {,SSR } 85\end{array}$ \\
\hline 3 & 21 & 10 & RM16, RM130, RM218, RM203,SSR 06, SSR 13, SSR 18, SSR 45, SSR 85, SSR 93 \\
\hline 4 & 18 & 12 & $\begin{array}{l}\text { RM241, RM307, RM401, RM55, RM471, RM518, RM470,SSR 04, SSR 10, SSR 19, } \\
\text { SSR 32, SSR } 40\end{array}$ \\
\hline 5 & 19 & 12 & $\begin{array}{l}\text { RM164, RM592, RM440, SSR 05, SSR 13, SSR 21, SSR 27, SSR 34,SSR 37, SSR 43, } \\
\text { SSR 50, SSR } 59\end{array}$ \\
\hline 6 & 20 & 10 & RM225, RM276, RM340, RM402, RM586, RM589, RM588, SSR 21, SSR 31, SSR 54 \\
\hline 7 & 21 & 9 & RM10, RM336, RM560, RM432, RM346, SSR 28, SSR 37, SSR 41, SSR 44 \\
\hline 8 & 20 & 10 & $\begin{array}{l}\text { RM223, RM241, RM407, RM3395, RM6208, RM22550, RM22506, RM8271, SSR } \\
14 \text {,SSR } 48\end{array}$ \\
\hline 9 & 16 & 7 & RM219, RM242, RM257, RM410, RM3555,SSR 40, SSR 42 \\
\hline 10 & 17 & 9 & RM171, RM216, RM333, RM330, SSR 03, SSR 06, SSR 11, SSR 25, SSR 30 \\
\hline 11 & 18 & 11 & $\begin{array}{l}\text { RM21, RM144, M202, RM206, RM209, RM260, RM287,SSR 3, SSR 4, SSR 11, SSR } \\
27\end{array}$ \\
\hline 12 & 17 & 7 & RM17, RM195, RM415, RM23, SSR 23, SSR 26, SSR 36 \\
\hline Total & 236 & 120 & \\
\hline
\end{tabular}

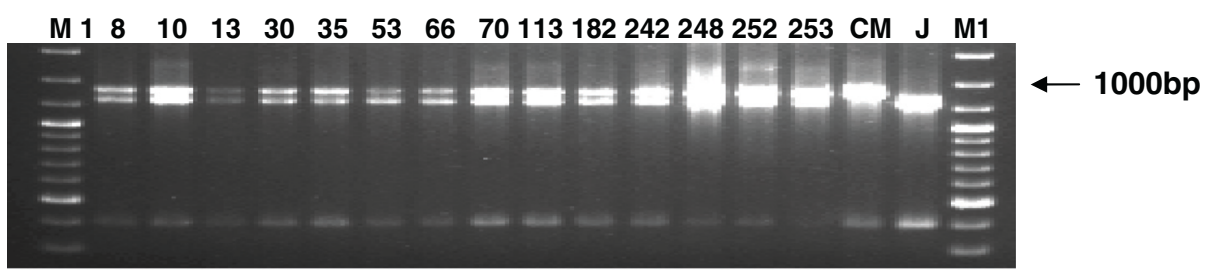

A

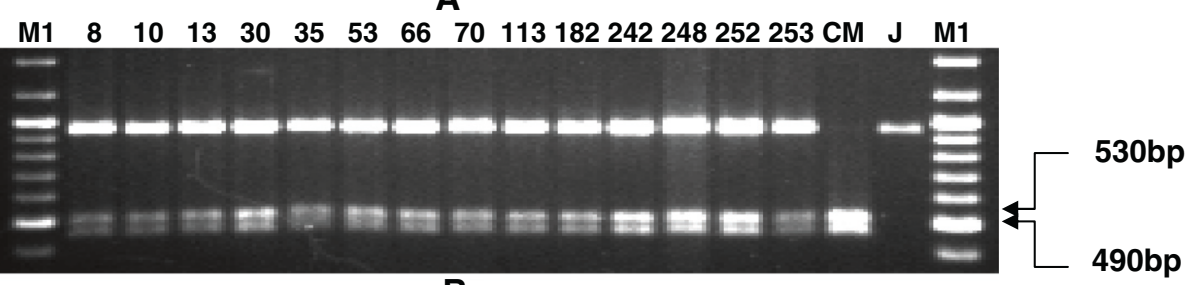

B

490bp

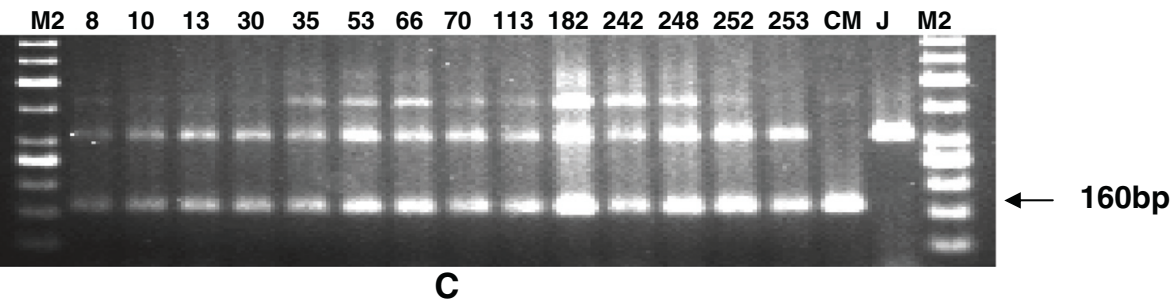

Figure 1 PCR amplification of markers linked to resistance genes Xa21, xa13 and xa5 using primers A) pAT248, B) RG136 and C) xa5S and $x a 5 R$ of $B C_{1} F_{1}$. Lanes on the top of the gel shows the $\mathrm{BC}_{1} \mathrm{~F}_{1}$ plant no., CM- CRMAS 2232-85, J-Jalmagna, M1-Molecular weight marker (100bp plus ladder), M2-Molecular weight marker (50bp ladder), Arrows indicate the resistance specific markers. 


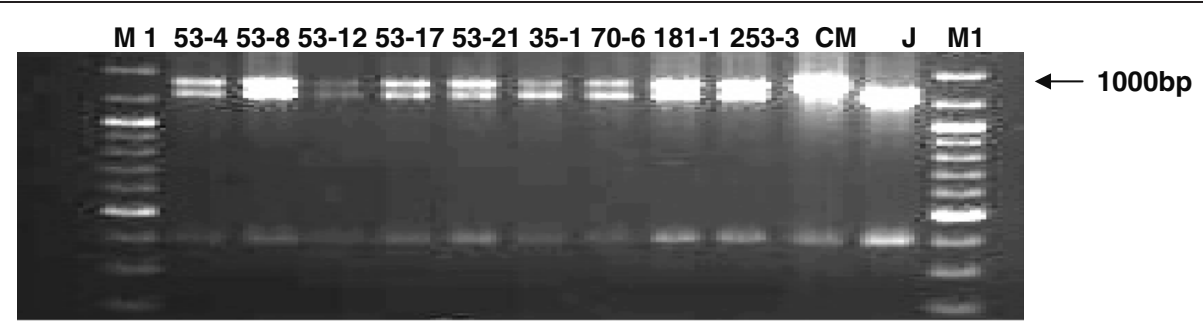

A

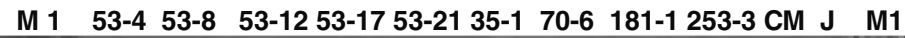

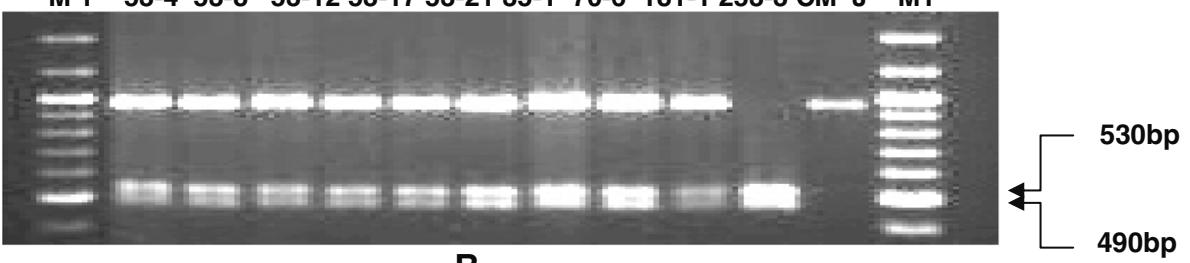

B

490bp

M2 53-4 53-8 53-12 53-1753-21 35-1 70-6 181-1 253-3 CM J M2

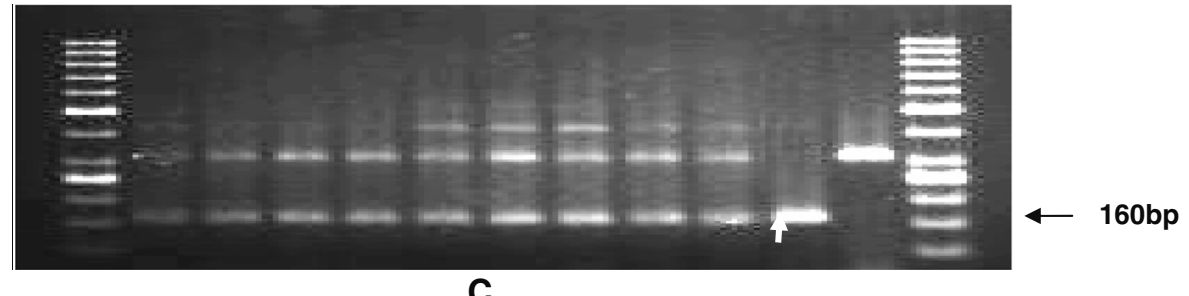

Figure 2 PCR amplification of markers linked to resistance genes Xa21, xa13 and $x a 5$ using primers A) pAT248, B) RG136 and C) $x a 55$ and $x a 5 R$ of $\mathrm{BC}_{2} \mathrm{~F}_{1}$. Lanes on the top of the gel shows the $\mathrm{BC}_{2} \mathrm{~F}_{1}$ plant no., CM- CRMAS 2232-85, J-Jalmagna, M1-Molecular weight marker (100bp plus ladder), M2-Molecular weight marker (50bp ladder).

Only fourteen plants showed the presence of three BB resistance genes $X a 21, x a 13$ and $x a 5$. Out of these 14 $\mathrm{BC}_{1} \mathrm{~F}_{1}$ progenies, plant showing $77.5 \%$ of recurrent genome (Plant No.53) was backcrossed with recurrent parent Jalmagna (Table 3 ).

Total of $122 \mathrm{BC}_{2} \mathrm{~F}_{1}$ progenies were produced of which, twenty one, thirty three and thirty six $\mathrm{BC}_{2} \mathrm{~F}_{1}$ plants showed presence of resistance genes, Xa21, xa13 and $x a 5$, respectively. Based on the amplification pattern, 11 $\mathrm{BC}_{2} \mathrm{~F}_{1}$ plants showed the presence of $\mathrm{Xa21}$ and $x a 13$ resistance genes while $13 \mathrm{BC}_{2} \mathrm{~F}_{1}$ plants showed the presence of $\mathrm{Xa21}$ and $x a 5$ resistance genes. Twenty three $\mathrm{BC}_{2} \mathrm{~F}_{1}$ plants showed the presence of $x a 13$ and $x a 5$ resistance genes. Only nine plants exhibited the amplification of three resistance genes $\mathrm{Xa21}, x a 13$ and $x a 5$. The background selection of these nine $\mathrm{BC}_{2} \mathrm{~F}_{1}$ plants with sixty polymorphic SSR markers exhibited the presence of $88.13 \%$ to $91.82 \%$ with an average of $90.95 \%$ of recurrent genome content. The plant containing $91.82 \%$ genome content of Jalmagna (Plant No.53-21) was used for backcrossing (Table 3).

A total of $285 \mathrm{BC}_{3} \mathrm{~F}_{1}$ backcross derivative progenies were produced by backcrossing the plant showing 91.82\% recurrent genome with the recipient parent, Jalmagna. Twenty eight $\mathrm{BC}_{3} \mathrm{~F}_{1}$ plants were positive for $\mathrm{Xa}$
21, 35 for $x a 5$ and 14 for $x a 13$. Eighteen $\mathrm{BC}_{3} \mathrm{~F}_{1}$ plants showed the presence of $X a 21$ and $x a 13$ resistance genes while 14 plants showed the presence of Xa21 and $x a 5$ resistance genes and 14 plants showed the presence of $x a 13$ and $x a 5$ resistance genes. Only fourteen plants showed the presence of three resistance genes $\mathrm{Xa21}$, $x a 13$ and $x a 5$. These $\mathrm{BC}_{3} \mathrm{~F}_{1}$ plants showed recurrent genome content of Jalmagna ranging from 91 to $97 \%$ with an average of $92.38 \%$ (Table 3 ). $\mathrm{BC}_{3} \mathrm{~F}_{1}$ derivative SPJ53-21-77 and and SPJ53-21- 25 showed more than 95\% genome content of recipient parent were self pollinated to obtain the derivatives of $\mathrm{BC}_{3} \mathrm{~F}_{2}$ generation. In $\mathrm{BC}_{3} \mathrm{~F}_{2}$ generation, plants homozygous for three and two bacterial blight resistance gene combinations were identified. It is observed that 26 plants containing $\mathrm{Xa21}$, xa13 and xa5 genes; 31 plants with Xa21 and xa5; 31 plants with Xa21, xa13 and 30 with xa13 and xa5 amongst the $\mathrm{BC}_{3} \mathrm{~F}_{2}$ derivatives. The plants with three and two genes were grown as $\mathrm{BC}_{3} \mathrm{~F}_{3}$ lines.

\section{Bioassays}

Bioassays conducted against eight isolates of Xoo confirmed the resistance and susceptible reaction of the donor (CRMAS 2232-85) and the recurrent (Jalmagna) respectively with the donor showing smaller range of 


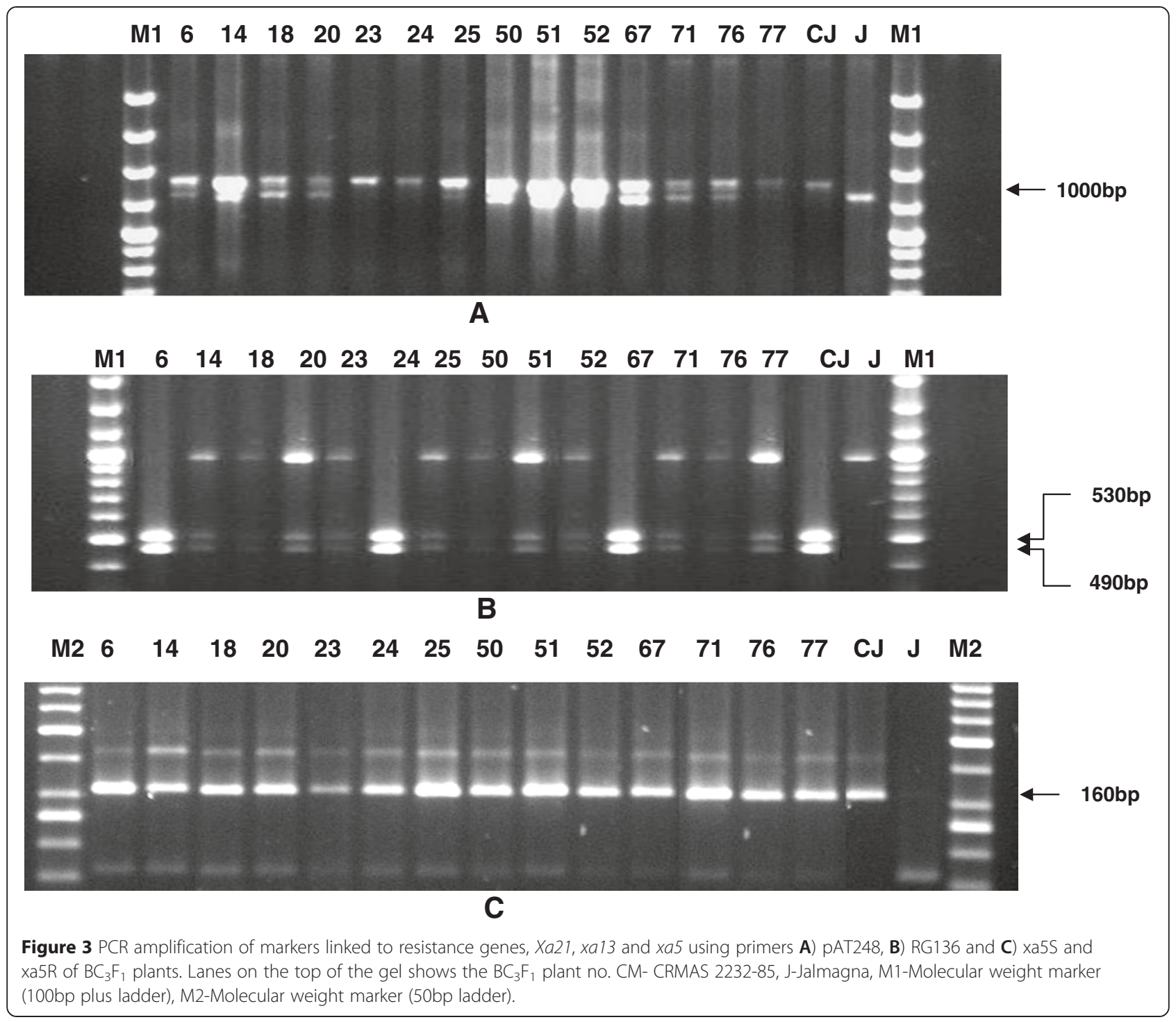

Table 3 Number of triple resistant gene heterozygotes identified and estimation of recurrent parent genome contribution

\begin{tabular}{lllll}
\hline $\begin{array}{l}\text { Generation } \\
\text { plantsscored }\end{array}$ & $\begin{array}{l}\text { \# of plants that } \\
\text { are triple heterozygotes }\end{array}$ & $\begin{array}{l}\text { Estimated maximum \% contribution of } \\
\text { recurrent parent genome to selected } \\
\text { backcross plant }^{c}\end{array}$ & $\begin{array}{l}\text { Expected \% contribution of recurrent } \\
\text { parent genome to selected backcross } \\
\text { plant }^{\mathbf{d}}\end{array}$ \\
\hline $\mathrm{BC}_{1} \mathrm{~F}_{1}$ & 360 & 14 & 77.5 & 77.5 \\
$\mathrm{BC}_{2} \mathrm{~F}_{1}$ & 122 & 9 & 91.8 & 91.8 \\
$\mathrm{BC}_{3} \mathrm{~F}_{1}$ & 285 & 14 & 97 & 97 \\
\hline
\end{tabular}

${ }^{\mathrm{a} A t}$ each backcross generation, genomic DNA was isolated from derivative lines and genotyping was performed using primers that are tightly linked to BB resistant genes as described in Materials and methods.

${ }^{b}$ At each backcross generation, fewer than expected triple heterozygotes were obtained. This is due to the fact that some of the putative backcross progeny were obtained by inadvertent selfing of Jalmagna (the female parent in these backcrosses).

'At each backcross generation, genomic DNA was isolated from derivative lines that are triple heterozygotes for BB resistant gene linked markers. Microsatellite markers that are polymorphic between the parental lines were then used, as described in Materials and Methods, to identify the plant with maximum recurrent parent genome contribution.

${ }^{\mathrm{d}}$ As per Mendelian ratios for independent gene action. 
average lesion lengths $(2.1-2.8 \mathrm{~cm})$ while on Jalmagna, the lesion lengths were longer $(9.4-12.8 \mathrm{~cm})$ (Table 4). The results indicated that the pyramided lines were better as compared to recurrent parent, Jalmagna with regard to bacterial leaf blight tolerance. Screening of the $\mathrm{BC}_{3} \mathrm{~F}_{3}$ pyramided lines against $\mathrm{Xoo}$ isolates exhibited that all the pyramid lines were more effective in comparison to the recipient parent. The lesion lengths observed on the lines containing $\mathrm{Xa21}+x a 13$ gene combination varied from 3.1 to $3.9 \mathrm{~cm}$; for $\mathrm{Xa} 21+\mathrm{xa} 5$ combination, $3.5-4.8 \mathrm{~cm}$; for $x a 5+x a 13$ combination 4.9 to 5.7 while 1.4 to $2.9 \mathrm{~cm}$ lesion length present in pyramided line containing $x a 5+x a 13+X a 21$ combination. The individual values for the donor parent and recurrent parent are in the range of $1.7-3.3$ and 9.0$13.3 \mathrm{~cm}$ respectively. Though all the gene combinations tested did not show any susceptible reaction to any of the eight isolates employed, the gene pyramids with three genes displayed higher levels of disease resistance with shorter lesion lengths against all BB isolates. Results indicated that the degree of severity of the disease from the data, the order of gene combinations in conferring resistance was: $x a 5+x a 13<x a 5+X a 21<x a 13+X a 21<$ $x a 5+x a 13+X a 21$.

\section{Yield and agro-morphological traits of the pyramided lines}

Fourteen three-gene pyramid and six two genes pyramid lines at $\mathrm{BC}_{3} \mathrm{~F}_{3}$ generation along with the donor and recipient parents were evaluated during wet season, 2013 at CRRI, Cuttack. The recipient parent, Jalmagna recorded mean grain yield of $17.35 \mathrm{~g} /$ plant, while the donor parent (Swarna BB pyramided line) recorded $20.5 \mathrm{~g} /$ plant. The test entries viz., SPJ23, SPJ25, SPJ50, SPJ51, SPJ52 and SPJ77 showed grain yields higher than recurrent parent, Jalmagna (Table 5). Many test entries did not show any significant variation as compared to Jalmagna in terms of flowering duration, panicles $/ \mathrm{m}^{2}$, plant stature as well as other characters that are considered under distinctness, uniformity and stability (DUS) tests. The genetic distance coefficient on 14 agromorphologic traits of 20 pyramids and two parental lines revealed that two clusters were observed and it is interesting to note that all the pyramided lines are similar to

Table 4 Bacterial blight reaction of parental and $\mathrm{BC}_{3} \mathrm{~F}_{3}$ pyramided lines against different Xoo strains

\begin{tabular}{|c|c|c|c|c|c|c|c|c|c|c|c|}
\hline \multirow[t]{2}{*}{ SI.No. } & \multirow{2}{*}{$\begin{array}{l}\text { Pyramided } \\
\text { lines } / \text { Xoo } \\
\text { strains }\end{array}$} & \multirow[t]{2}{*}{ Gene combination } & \multicolumn{9}{|c|}{ Mean lesion length in $\mathrm{cm}$ (Mean \pm standard error) } \\
\hline & & & $\overline{\mathrm{Xa}-17}$ & Xa-7 & xa-2 & $x b-7$ & xc-4 & $x d-1$ & xa-1 & $x a-5$ & $\begin{array}{l}\text { Disease } \\
\text { reaction }\end{array}$ \\
\hline$\overline{1}$ & SPJ 53-21-06 & $x a 21+x a 13+x a 5$ & $2.8 \pm 0.4$ & $2.5 \pm 0.8$ & $2.7 \pm 0.9$ & $1.9 \pm 1.1$ & $2.7 \pm 1.0$ & $2.6 \pm 0.75$ & $2.4 \pm 0.56$ & $2.5 \pm 0.47$ & $\mathrm{R}$ \\
\hline 2 & SPJ 53-21-14 & $x a 21+x a 13+x a 5$ & $2.6 \pm 0.6$ & $2.7 \pm 0.4$ & $2.5 \pm 1.1$ & $2.5 \pm 0.8$ & $2.9 \pm 0.7$ & $2.8 \pm 0.64$ & $2.3 \pm 0.43$ & $2.3 \pm 0.64$ & $\mathrm{R}$ \\
\hline 3 & SPJ 53-21-18 & $x a 21+x a 13+x a 5$ & $2.7 \pm 0.3$ & $2.9 \pm 0.5$ & $2.8 \pm 1.2$ & $1.8 \pm 0.9$ & $2.1 \pm 0.9$ & $2.3 \pm 0.37$ & $1.9 \pm 0.72$ & $2.1 \pm 0.75$ & $\mathrm{R}$ \\
\hline 4 & SPJ 53-21- 20 & $x a 21+x a 13+x a 5$ & $2.8 \pm 0.3$ & $2.5 \pm 0.4$ & $2.7 \pm 0.7$ & $1.6 \pm 0.5$ & $1.6 \pm 1.2$ & $1.9 \pm 0.52$ & $2.6 \pm 0.54$ & $1.7 \pm 0.83$ & $\mathrm{R}$ \\
\hline 5 & SPJ 53-21- 23 & $x a 21+x a 13+x a 5$ & $2.7 \pm 0.5$ & $2.6 \pm 0.6$ & $2.6 \pm 1.5$ & $2.1 \pm 0.7$ & $1.8 \pm 1.1$ & $1.7 \pm 0.93$ & $2.8 \pm 0.71$ & $1.4 \pm 0.85$ & $\mathrm{R}$ \\
\hline 6 & SPJ 53-21-24 & $x a 21+x a 13+x a 5$ & $2.9 \pm 0.4$ & $2.8 \pm 0.7$ & $2.8 \pm 0.5$ & $2.3 \pm 0.4$ & $1.9 \pm 1.3$ & $2.9 \pm 0.33$ & $2.5 \pm 0.83$ & $2.5 \pm 0.52$ & $\mathrm{R}$ \\
\hline 7 & SPJ 53-21-25 & $x a 21+x a 13+x a 5$ & $2.9 \pm 0.5$ & $2.7 \pm 0.9$ & $2.9 \pm 1.3$ & $2.4 \pm 0.6$ & $2.8 \pm 0.8$ & $2.6 \pm 0.84$ & $2.4 \pm 0.95$ & $2.7 \pm 0.44$ & $\mathrm{R}$ \\
\hline 8 & SPJ 53-21-50 & $x a 21+x a 13+x a 5$ & $2.8 \pm 0.3$ & $2.4 \pm 0.5$ & $2.7 \pm 0.7$ & $1.6 \pm 1.1$ & $2.6 \pm 0.7$ & $2.1 \pm 0.72$ & $1.7 \pm 1.2$ & $1.7 \pm 0.92$ & $\mathrm{R}$ \\
\hline 9 & SPJ 53-21-51 & $x a 21+x a 13+x a 5$ & $2.9 \pm 0.4$ & $2.7 \pm 0.4$ & $2.5 \pm 0.8$ & $2.3 \pm 0.7$ & $2.1 \pm 0.6$ & $1.6 \pm 0.94$ & $2.9 \pm 0.52$ & $1.4 \pm 1.1$ & $\mathrm{R}$ \\
\hline 1 & SPJ 53-21-52 & $x a 21+x a 13+x a 5$ & $2.7 \pm 0.3$ & $2.8 \pm 0.7$ & $2.8 \pm 1.1$ & $1.7 \pm 0.8$ & $2.9 \pm 0.5$ & $2.2 \pm 0.88$ & $2.9 \pm 0.47$ & $1.9 \pm 1.2$ & $\mathrm{R}$ \\
\hline 11 & SPJ 53-21-67 & $x a 21+x a 13+x a 5$ & $2.5 \pm 0.7$ & $2.6 \pm 0.9$ & $2.6 \pm 0.3$ & $1.9 \pm 0.9$ & $2.8 \pm 0.8$ & $2.5 \pm 1.12$ & $1.8 \pm 0.85$ & $2.3 \pm 0.53$ & $\mathrm{R}$ \\
\hline 12 & SPJ 53-21-71 & $x a 21+x a 13+x a 5$ & $2.6 \pm 0.6$ & $2.5 \pm 0.5$ & $2.5 \pm 0.7$ & $2.2 \pm 1.0$ & $2.8 \pm 0.4$ & $2.7 \pm 0.85$ & $2.3 \pm 0.63$ & $2.8 \pm 0.44$ & $\mathrm{R}$ \\
\hline 13 & SPJ 53-21-76 & $x a 21+x a 13+x a 5$ & $2.8 \pm 0.4$ & $2.6 \pm 0.7$ & $2.7 \pm 0.6$ & $2.1 \pm 0.6$ & $2.9 \pm 0.5$ & $2.9 \pm 0.67$ & $2.6 \pm 0.52$ & $2.9 \pm 0.52$ & $\mathrm{R}$ \\
\hline 14 & SPJ 53-21-77 & $x a 21+x a 13+x a 5$ & $2.9 \pm 0.3$ & $2.7 \pm 0.9$ & $2.8 \pm 1.2$ & $2.4 \pm 0.5$ & $2.8 \pm 0.4$ & $2.9 \pm 0.69$ & $2.8 \pm 0.73$ & $2.8 \pm 0.55$ & $\mathrm{R}$ \\
\hline 15 & SPJ 53-21-27 & $x a 21+x a 13$ & $3.6 \pm 0.4$ & $3.4 \pm 1.1$ & $3.5 \pm 1.1$ & $3.1 \pm 0.6$ & $3.4 \pm 0.7$ & $3.7 \pm 0.4$ & $3.6 \pm 1.2$ & $3.7 \pm 0.63$ & $\mathrm{MR}$ \\
\hline 16 & SPJ 53-21-15 & $x a 21+x a 13$ & $3.9 \pm 0.5$ & $3.8 \pm 1.2$ & $3.6 \pm 1.0$ & $3.7 \pm 0.5$ & $3.7 \pm 0.9$ & $3.8 \pm 0.77$ & $3.4 \pm 1.1$ & $3.85 \pm 0.7$ & $\mathrm{MR}$ \\
\hline 17 & SPJ 53-21-38 & $x a 21+x a 5$ & $4.1 \pm 0.5$ & $3.7 \pm 1.4$ & $3.9 \pm 0.7$ & $3.5 \pm 0.6$ & $3.7 \pm 1.2$ & $4.3 \pm 0.7$ & $4.2 \pm 0.4$ & $3.9 \pm 0.7$ & $M R$ \\
\hline 18 & SPJ 53-21-66 & $x a 21+x a 5$ & $4.5 \pm 0.8$ & $3.9 \pm 1.3$ & $4.4 \pm 0.6$ & $4.8 \pm 0.8$ & $3.9 \pm 0.9$ & $4.3 \pm 0.5$ & $4.2 \pm 0.63$ & $4.1 \pm 0.65$ & $\mathrm{MR}$ \\
\hline 19 & SPJ 53-21-13 & $x a 13+x a 5$ & $5.6 \pm 1.1$ & $5.3 \pm 0.8$ & $5.1 \pm 0.6$ & $4.9 \pm 0.7$ & $5.5 \pm 1.3$ & $5.3 \pm 0.49$ & $5.7 \pm 0.72$ & $4.9 \pm 0.53$ & MR \\
\hline 20 & SPJ 53-21-36 & $x a 13+x a 5$ & $5.4 \pm 0.7$ & $5.1 \pm 0.8$ & $5.0 \pm 0.7$ & $5.2 \pm 0.7$ & $5.6 \pm 0.9$ & $5.1 \pm 0.76$ & $5.2 \pm 0.84$ & $5.3 \pm 0.65$ & $M R$ \\
\hline 21 & CRMAS2232-85 & $x a 21+x a 13+x a 5$ & $2.8 \pm 0.4$ & $2.5 \pm 0.3$ & $2.4 \pm 0.4$ & $2.1 \pm 0.4$ & $2.8 \pm 0.5$ & $2.4 \pm 0.4$ & $2.6 \pm 0.8$ & $2.2 \pm 0.6$ & $\mathrm{R}$ \\
\hline 22 & Jalmagna & - & $12.6 \pm 1.7$ & $11.4 \pm 1.4$ & $12.8 \pm 1.5$ & $9.4 \pm 1.2$ & $11.6 \pm 1.6$ & $9.8 \pm 1.8$ & $10.2 \pm 1.7$ & $11.6 \pm 1.8$ & S \\
\hline
\end{tabular}


Table 5 Agro-morphologic traits of pyramided and parental lines in $\mathrm{BC}_{3} \mathrm{~F}_{3}$ generation

\begin{tabular}{|c|c|c|c|c|c|c|c|c|c|c|c|c|c|c|c|c|}
\hline $\begin{array}{l}\text { Pyramided } \\
\text { lines }\end{array}$ & $\begin{array}{l}\text { Plant } \\
\text { height } \\
\text { (cm) } \\
\end{array}$ & $\begin{array}{l}\text { Days to } \\
50 \% \\
\text { flow }\end{array}$ & $\begin{array}{l}\text { Panicles/ } \\
\text { plant }\end{array}$ & $\begin{array}{l}\text { Panicle } \\
\text { length }(\mathrm{cm})\end{array}$ & $\begin{array}{l}\text { No of } \\
\text { grains/ } \\
\text { panicle }\end{array}$ & $\begin{array}{l}\text { Fertility } \\
\%\end{array}$ & $\begin{array}{l}1000- \\
\text { seed } \\
\text { weight(g) }\end{array}$ & $\begin{array}{l}\text { Single } \\
\text { plant } \\
\text { yield(g) }\end{array}$ & $\begin{array}{l}\text { Grain } \\
\text { length } \\
(\mathrm{mm})\end{array}$ & $\begin{array}{l}\text { Grain } \\
\text { Breadth } \\
(\mathrm{mm})\end{array}$ & $\begin{array}{l}\text { Flag leaf } \\
\text { length }(\mathrm{cm})\end{array}$ & $\begin{array}{l}\text { Flag leaf } \\
\text { breadth } \\
(\mathrm{cm})\end{array}$ & $\begin{array}{l}2^{\text {nd }} \text { leaf } \\
\text { length } \\
(\mathrm{cm})\end{array}$ & $\begin{array}{l}2^{\text {nd }} \text { leaf } \\
\text { breadth } \\
(\mathrm{cm})\end{array}$ & $\begin{array}{l}\text { Auricle } \\
\text { colour }\end{array}$ & $\begin{array}{l}\text { Collar } \\
\text { colour }\end{array}$ \\
\hline SPJ 53-21-06 & 150 & 122 & 10 & 21.95 & 211.5 & 87 & 22.45 & 16.15 & 0.76 & 0.88 & 36.0 & 1.2 & 69.0 & 1.2 & Green & yellowish \\
\hline SPJ 53-21-14 & 178 & 124 & 12 & 22.1 & 204 & 86 & 22.05 & 16.85 & 0.73 & 0.875 & 39.0 & 1.2 & 49.0 & 1.2 & Green & yellowish \\
\hline SPJ 53-21-18 & 163.5 & 121 & 11 & 26.25 & 205.5 & 84 & 21.6 & 17 & 0.67 & 0.89 & 41.0 & 0.9 & 59.0 & 0.9 & Green & yellowish \\
\hline SPJ 53-21- 20 & 172.5 & 124 & 11 & 26.25 & 208 & 84 & 22.7 & 17.1 & 0.75 & 0.86 & 47.0 & 1.2 & 75.0 & 1.2 & Green & yellowish \\
\hline SPJ 53-21- 23 & 158.5 & 123 & 12 & 24.2 & 207.5 & 83 & 21.5 & 16.5 & 0.74 & 0.88 & 45.0 & 1.1 & 58.0 & 1.1 & Green & yellowish \\
\hline SPJ 53-21-24 & 153.5 & 122 & 9 & 21.25 & 200.5 & 84 & 23.25 & 16.65 & 0.75 & 0.88 & 35.0 & 1.1 & 41.0 & 1.1 & Green & $\begin{array}{l}\text { Light } \\
\text { purple }\end{array}$ \\
\hline SPJ 53-21-25 & 151.5 & 123 & 8 & 22.8 & 199 & 82 & 21.35 & 16.65 & 0.75 & 0.87 & 47.5 & 1.2 & 56.0 & 1.2 & Green & Green \\
\hline SPJ 53-21-50 & 177 & 125 & 10 & 24.95 & 203.5 & 86 & 23.05 & 16.85 & 0.75 & 0.87 & 35.0 & 1.2 & 62.0 & 1.2 & Green & $\begin{array}{l}\text { Light } \\
\text { purple }\end{array}$ \\
\hline SPJ 53-21-51 & 152.5 & 123 & 10 & 24.95 & 208.5 & 82 & 21.5 & 17.95 & 0.745 & 0.87 & 43.0 & 1.1 & 69.0 & 1.1 & Green & yellowish \\
\hline SPJ 53-21-52 & 177 & 121 & 11 & 21.9 & 200.5 & 83 & 23 & 16.65 & 0.75 & 0.85 & 34.0 & 1.0 & 43.0 & 1.0 & Green & yellowish \\
\hline SPJ 53-21-67 & 178.5 & 122 & 9 & 24.95 & 203 & 85.5 & 21.05 & 17 & 0.745 & 0.86 & 36.0 & 1.2 & 54.0 & 1.2 & Green & yellowish \\
\hline SPJ 53-21-71 & 176.5 & 120 & 10 & 25.6 & 208 & 85 & 20.1 & 16.85 & 0.74 & 0.875 & 46.0 & 1.1 & 63.0 & 1.1 & Green & yellowish \\
\hline SPJ 53-21-76 & 182 & 123 & 11 & 25.45 & 205.5 & 84 & 21.65 & 16.55 & 0.74 & 0.88 & 38.0 & 1.0 & 70.0 & 1.0 & Green & yellowish \\
\hline SPJ 53-21-77 & 183 & 124 & 12 & 23.4 & 203 & 86 & 19.5 & 18.2 & 0.74 & 0.89 & 39.0 & 1.2 & 54.0 & 1.2 & Green & yellowish \\
\hline SPJ 53-21-27 & 161.5 & 123 & 11 & 24.75 & 200.5 & 85.5 & 21.8 & 17.15 & 0.725 & 0.88 & 32.5 & 1.5 & 55.0 & 1.5 & Green & yellowish \\
\hline SPJ 53-21-15 & 158.5 & 122 & 9 & 26.05 & 196.5 & 83.5 & 20.1 & 18.3 & 0.74 & 0.86 & 33.6 & 1.4 & 47.0 & 1.4 & Green & yellowish \\
\hline SPJ 53-21-38 & 170 & 119 & 10 & 26.05 & 196.5 & 87 & 22.05 & 17.15 & 0.72 & 0.89 & 34.2 & 1.3 & 56.2 & 1.3 & purple & Purple \\
\hline SPJ 53-21-66 & 153.5 & 125 & 11 & 25.05 & 198.5 & 86 & 21.95 & 16.8 & 0.73 & 0.88 & 33.7 & 1.4 & 58.5 & 1.4 & Green & yellowish \\
\hline SPJ 53-21-13 & 169.5 & 124 & 11 & 25.15 & 204.5 & 88 & 21.9 & 18.25 & 0.74 & 0.87 & 34.1 & 1.5 & 51.7 & 1.5 & Green & yellowish \\
\hline SPJ 53-21-36 & 152 & 123 & 12 & 24 & 208.5 & 84 & 21.8 & 16.3 & 0.74 & 0.88 & 34.4 & 1.3 & 53.4 & 1.3 & Purple & Purple \\
\hline CRMAS 2232-85 & 105.5 & 105 & 12 & 24.15 & 218 & 84.5 & 18.2 & 20.5 & 0.72 & 0.84 & 34.0 & 2.0 & 33.0 & 2.0 & Green & yellowish \\
\hline Jalmagna & 174 & 130 & 9 & 24.95 & 186 & 85.5 & 23.2 & 17.35 & 0.75 & 0.88 & 28.0 & 1.5 & 52.0 & 1.5 & Purple & Purple \\
\hline $\mathrm{LSD}_{5} \%$ & 15.85 & & 3.075 & 1.68 & 46.67 & 7.01 & 1.42 & 4.47 & 0.86 & 0.108 & 6.048 & 0.424 & 7.76 & 0.47 & & \\
\hline CV\% & 4.7 & & 14.1 & 3.3 & 11.0 & 4.0 & 3.2 & 12.5 & 5.6 & 6.0 & 7.7 & 16.2 & 6.7 & 17.8 & & \\
\hline
\end{tabular}


the recipient parent, Jalmagna and are clubbed in cluster1 while in cluster 2, only solitary line the donor parent is accommodated. (Table 5; Figure 4A).

\section{Background selection}

The background selection was carried out for estimating the recurrent parent's genome content in the pyramided lines. Background selection was performed by using 60 SSR markers among the lines possessing three resistance gene combinations in $\mathrm{BC}_{1} \mathrm{~F}_{1}, \mathrm{BC}_{2} \mathrm{~F}_{1}$ and $\mathrm{BC}_{3} \mathrm{~F}_{1}$ generations. At $\mathrm{BC}_{3} \mathrm{~F}_{1}$ generation, a total of 120 alleles from 60 markers were observed. The similarity co-efficiency among all lines ranged from 0.791 to 0.952 suggesting a high level of genetic similarity between the pyramids and Jalmagna. The dendrogram generated using the SSR data grouped the 14 three-gene pyramid lines into two major clusters (Figure 4B) with cluster I having CRMAS
2232-85 and rest 13 pyramided lines were clubbed in cluster II along with Jalmagna. Few members of cluster II viz., SPJ53-21-77, SPJ53-21-25, SPJ53-21-52 and SPJ53-21-18 were very close to Jalmagna with $97,95.33$, 92.48 and $92.48 \%$ respectively.

\section{Analysis of genome introgression on the carrier and non- carrier chromosomes}

In CRMAS2232-85/Jalmagna combination, 5-6 microsatellite markers on each of three carrier chromosomes in the genomic region flanking to $x a 5, x a 13$ and $\mathrm{Xa21}$ were polymorphic. Based on six markers analysis, all the 14 lines showed heterozygosity for donor segment introgression of $x a 5$ between marker HYV59 and HYV5-37 in $\mathrm{BC}_{3} \mathrm{~F}_{1}$ generation while exhibited homozygocity for Jalmagna genome and no drag to $x a 5$ gene was observed. In the flanking region of xa13, for five

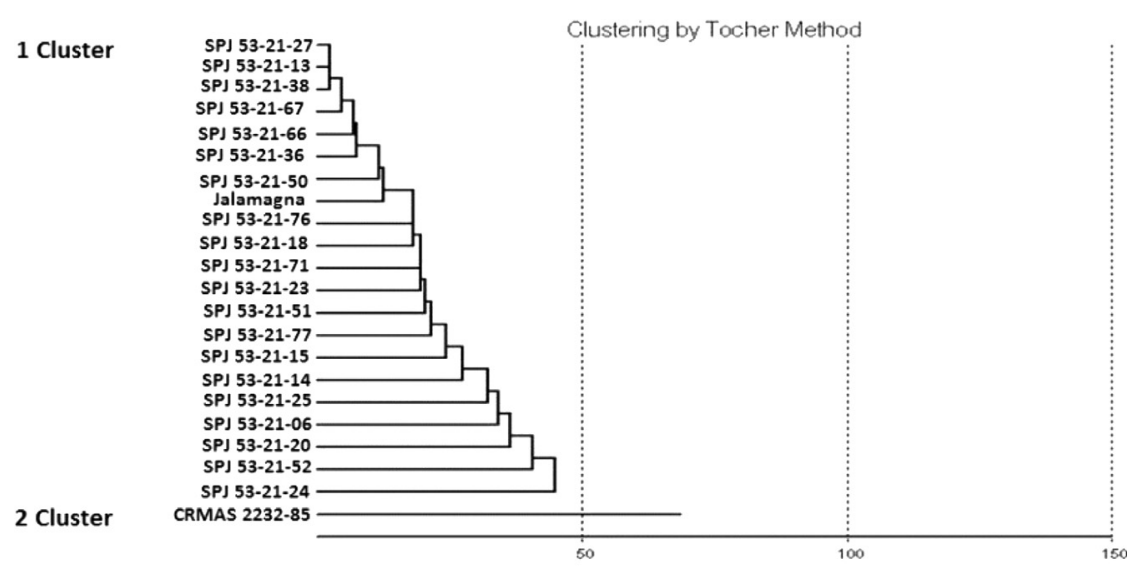

A

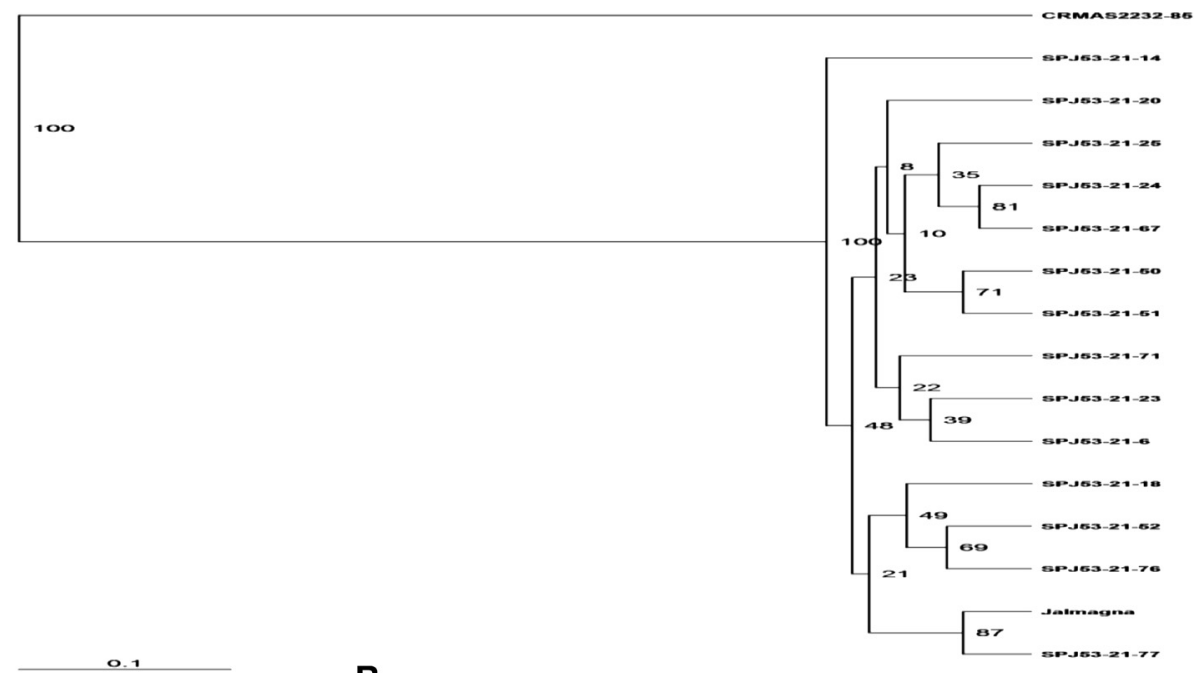

Figure 4 Dendrograms illustrating the genetic relationship between parents and pyramided lines (A) based on 14 agro-morphological traits; (B) based on microsatellite markers. 
polymorphic markers, nine lines showed introgression of the donor segment of marker HYV14. In case of Xa21, six pyramid lines showed genetic drag of donor segment with the marker segment RM144 (Figure 5).

\section{Discussion}

Integration of molecular markers to the backcross breeding was highly effective for transfer of three bacterial blight resistance genes. Phenotypic selections in three backcrossing and two selfing generations coupled with SSR based background selection was sufficient for transfer of Xa21, xa13 and $x a 5$ genes into popular deepwater variety Jalmagna background. Jalmagna is a very long duration and strongly photo-sensitive variety. Again under deepwater situation, control of the disease using chemicals was a very difficult task. Here, integrating molecular markers and using very less generations and advancement of some generations under RGA helped to obtain the broad spectrum BB resistant lines for deepwater ecology. The transferred genes in the recombinants did exhibit high level of resistance against the most virulent $\mathrm{BB}$ isolates that is comparable to the reaction level of CRMAS 2232-85, the donor parent and the results are similar to earlier reports (Huang et al. 1997; Sanchez et al. 2000; Singh et al. 2001; Shanti et al. 2001; Bharatkumar et al. 2008; Hu et al. 2008; Perez et al. 2008; Sundaram et al., 2008; Rajpurohit et al., 2011;
Dokku et al., 2013; Suh et al., 2013). The three gene combination pyramided lines expressed higher levels of resistance in comparison to parental lines, two and single gene combination. The results suggest that two gene combinations with $\mathrm{Xa21}+x a 13$ was most effective with shorter lesions lengths followed by Xa21+xa5 while lines with xa13+xa5 were relatively less effective. Lines with $X a 21$ in combination with either $x a 5, x a 13$, or both have shown promise advocating the utility of Xa21 in achieving higher levels of resistance in rice as reported earlier (Singh et al. 2001; Sanchez et al. 2000; Sridhar et al. 1999; Huang et al. 1997) suggesting that synergistic action and/or quantitative complementation between the resistant genes might result in enhanced levels of resistance (Sanchez et al. 2000).

All the three resistance genes that have been considered in the present work have been cloned and characterized. Xa21 is a dominant resistance gene that encodes a receptor kinase containing NBS-LRR domains (Song et al. 1995), while $x a 5$ is a recessive resistance gene and encodes a variant form of transcription factor cIla (Iyer and McCouch 2004). The xa13 resistance gene is also recessive in nature and has been shown to be a mutation in the promoter region of a gene that is a homolog of the nodulin MtN3 (Chu et al. 2006b). In rice lines containing the dominant (susceptibility) allele of the gene, the expression of the nodulin homolog is up regulated

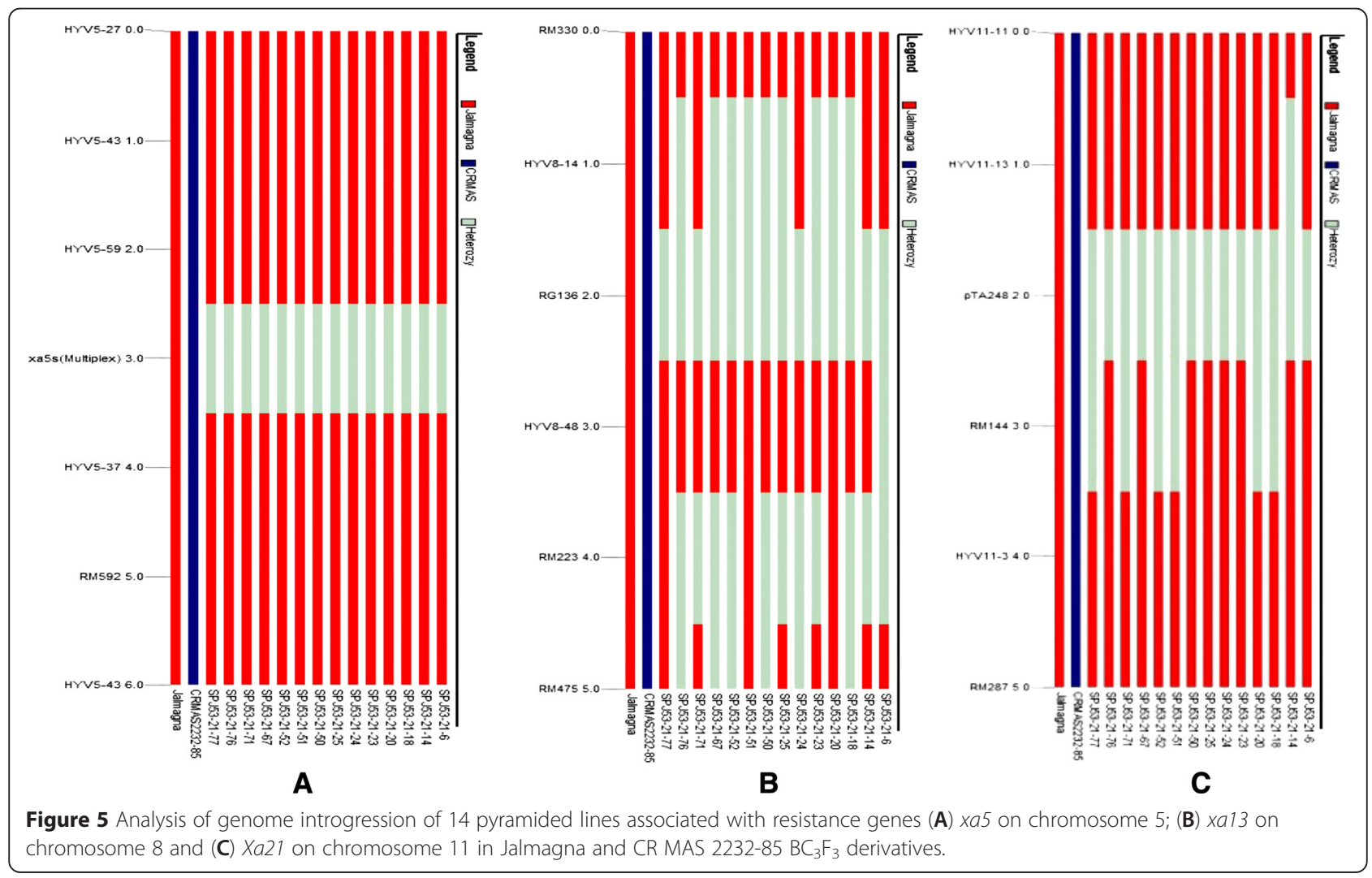


upon infection with Xoo. It appears that the increased expression of this gene is necessary for Xoo to grow on rice. This up regulation does not occur in rice lines containing the resistance (recessive) xa13 allele (Yang, 2006). The apparently different modes of action of the three resistance genes used in this work might contribute to make the resistance in the three-gene pyramid lines quite durable. There is a variation in the theoretically expected value of contribution from the recurrent parent genome to the $\mathrm{BC}_{1} \mathrm{~F}_{1}$ plants and in other backcross generations. As per reports of Sundaram et al. 2008, there might be exercising a "pull" for introgression of the Xa21, xa13 and $x a 5$ genes during selection, which favors inheritance of additional unlinked loci from the donor genome in $\mathrm{BC}_{1} \mathrm{~F}_{1}$ plants and $\mathrm{BC}_{2} \mathrm{~F}_{1}$ generation. But, we found no pull effect during the transfer of $\mathrm{Xa21}$, $x a 13$ and $x a 5$ genes to different backcross generations.

Selection of plants similar to the recurrent parent from $\mathrm{BC}_{3} \mathrm{~F}_{1}$ stage was the strategy followed in the study and the graphical genotyping data supports that view as genotype SPJ53-21-77 had 97\% of the recurrent parent genome having donor segments of target resistance genes $x a 5, x a 13$ and $X a 21$ and further no linkage drag in regions flanking $X a 21, x a 13$ and $x a 5$ is observed. The high recurrent genome recovery observed in many pyramid lines may be due to the use of more number of polymorphic microsatellite markers. Similar results were obtained in case of Sundaram et al. 2008; Dokku et al. 2013; Suh et al. 2013 suggesting more number of background markers. No genetic linkage drag was observed for the transfer of genes Xa21, xa13 and xa5 (Figure 5) may be due to mega variety used as the donor source for $\mathrm{BB}$ resistance genes. The mega variety, Swarna is a highly adapted variety for the favorable ecology. Results indicated that a broad based highly adapted variety as source of donor may give better performance and less drag as compared to the wild and land races as donor. It is expected that all the favorable genes are accumulated in the mega variety and subsequently transfer of some of these genes is improving further the background of the pyramided lines. The approach used in the study ensured the realization of the major objective resulting in the release of a cultivar with enhanced resistance to $\mathrm{BB}$ and accelerated recovery of recurrent genome with better yield.

Yield and agro-morphologic data of 20 pyramided two parental lines revealed that the pyramided lines possessed excellent features of recurrent parent and also yielding ability with tolerance to bacterial blight resistance. This indicates that some pyramid lines are very close to the recurrent parent and some are even better than the recurrent parent with respect to yield. The higher yield of the pyramided lines may be due to inheritance of some yield traits or QTLs of mega variety
(Swarna BB pyramid) used here as the donor parent, besides the recurrent parent Jalmagna to the pyramided line. The complete recovery of the yield and grain quality characters of Jalmagna along with transfer of three $\mathrm{BB}$ resistance genes of CRMAS 2232-85 is a very significant achievement. This is particularly so because yield and agro-morphologic traits is multigenic traits encoded by loci that are distributed across the rice genome. The traits recovery of Jalmagna was due to integration of many polymorphic markers in the backcross breeding program. As per our analysis, we find that there is a variation from the theoretically expected $75 \%$ contribution from the recurrent parent genome to the $\mathrm{BC}_{1} \mathrm{~F}_{1}$ plants. All the selected $\mathrm{BC}_{1} \mathrm{~F}_{1}$ plants had a recurrent parent genome contribution more than the expected $75 \%$. Again in $\mathrm{BC}_{2} \mathrm{~F}_{2}$, it had highest gemone content of $91.8 \%$ along with the target genes. During $\mathrm{BC}_{3} \mathrm{~F}_{1}$, the genome content of Jalmagna in selected derivative (SPJ53-21-77) was as high as $97 \%$. The background selection with many markers accelerated the recovery of recurrent genome suggests that selection for introgression of the $X a 21, x a 13$ and $x a 5$ genes has no antagonistic effects for yield and other traits.

The field evaluation of $\mathrm{BC}_{3} \mathrm{~F}_{3}$ progenies showed that the best entry had better yielding than the Jalmagna parent. Besides, BB resistance, the pyramided line. SPJ5321-77 was better yielder than its recurrent parent and equivalent to agro-morphological traits and grain quality features of the recurrent parent. The high levels of resistance to $\mathrm{BB}$ and the absence of any yield penalty due to accumulation of resistance genes in the pyramids provides us a successful example of the integrated approach of selection at both molecular and phenotypic levels for transfer of the desired trait(s) and recovery of the recurrent parental genome. Development of broad-spectrum resistance against $\mathrm{BB}$ in the Indian subcontinent is a major challenge due to the rich diversity of the agroclimatic zones where rice is cultivated, as well as the presence of a number of genetically distinct virulent Xoo strains in different geographical areas of India. Deployment of a three gene combination like $x a 5+x a 13+$ $X a 21$ can achieve durable and broad-spectrum resistance in many $\mathrm{BB}$ prone rice growing areas in India including the deepwater ecosystem. The study clearly establishes the utility of MAS in pyramiding recessive genes like $x a 5$ and $x a 13$, and dominant gene $X a 21$ to present a multiple gene barrier against one of the most destructive diseases of rice in a long duration, photosensitive and deepwater rice.

\section{Conclusion}

Marker-assisted backcrossing using functional markers reduce the risk of false selection in recombination between the molecular marker and the gene of interest. 
We were successful in identifying superior recombinations for three BB resistance genes (Xa21, xa13 and xa5) in the homozygous condition in a long duration, photosensitive and deepwater rice variety. The pyramided genotypes can be further be used for multilocation testing to be released as variety in the country or be used as potential $\mathrm{BB}$ resistance donors. The BB pyramided deepwater breeding lines, which are developed through MAS and phenotypic selection, will be of practical value in providing durable bacterial blight resistance in the deepwater growing region where control through chemicals under deepwater situation was less effective. These BB pyramided lines are expected to have a high impact on the yield stability and sustainability of deep water rice production.

\section{Methods}

\section{Plant materials and breeding method}

The donor parent CRMAS 2232-85, a derivative of Swarna and IRBB 60 cross contains three BB resistance genes $x a 5, x a 13$ and $X a 21$ in the background of mega variety Swarna. The donor parent was developed at Central Rice Research Institute (CRRI), Cuttack, India (Sundaram et al. 2014). The recurrent parent was Jalmagna, a highly popular variety of deepwater ecosystem of India but highly susceptible to bacterial blight disease. Jalmagna was hybridized with CRMAS 2232-85 and $F_{1}$ plants were backcrossed with recipient parent Jalmagna. Marker-assisted backcross method was followed up to $\mathrm{BC}_{3}$ generation and around 200 plants/lines were genotyped at each generation for the presence of the target genes and only positive plants having the resistance alleles were advanced to the next generation. Foreground selection continued till $\mathrm{BC}_{3} \mathrm{~F}_{3}$ to identify pure homozygous lines for all three target genes while background selection was up to $\mathrm{BC}_{3} \mathrm{~F}_{1}$ generation. Selection based on foreground, background and morphological traits was practiced from $\mathrm{BC}_{1} \mathrm{~F}_{1}$ onwards for identification of lines that were similar to the recurrent parent. Rapid Generation Advancement (RGA) facility was used during dry season as Jalmagna was a strongly photo-sensitive and very long duration variety. The schematic diagram for development of $\mathrm{BB}$ pyramided lines is presented in Figure 6.

\section{Screening for bacterial blight resistance}

For field evaluation against BB, the inoculums of eight predominant Xoo isolates of Orissa prepared by suspending the bacterial mass in sterile water to a concentration of aproximately $10^{9}$ cells $/ \mathrm{ml}$ (Kauffman et al. 1973). Four leaves from four different plants of each entry were clip inoculated at the maximum tillering stage and lesion lengths (LL) were recorded after 15 days. The disease symptoms were scored as resistant $(\mathrm{R}, \mathrm{LL} \leq$ $3.0 \mathrm{~cm}$ ), moderately resistant (MR, $3.0 \mathrm{~cm}<\mathrm{LL} \leq$ $6.0 \mathrm{~cm}$ ), moderately susceptible (MS, $6.0 \mathrm{~cm}<\mathrm{LL} \leq$ $9.0 \mathrm{~cm}$ ) or susceptible $(\mathrm{S}, \mathrm{LL}>9.0 \mathrm{~cm}$ ) (Amante-Bordeos et al. 1992).

\section{Characterization for agro-morphological traits}

Thirty days' old seedlings of the $\mathrm{BC}_{3} \mathrm{~F}_{3}$ pyramid lines and the parents (Jalmagna and CRMAS 2232-85) were transplanted in three rows with twenty five plants per row per entry at $15 \times 20 \mathrm{~cm}$ spacing under a randomized complete block design with two replications at the experimental farm of Central Rice Research Institute (CRRI), Cuttack. Data were recorded on ten plants from each entry and replication for agronomic traits like plant height, tillers/plant, panicle length, number of filled

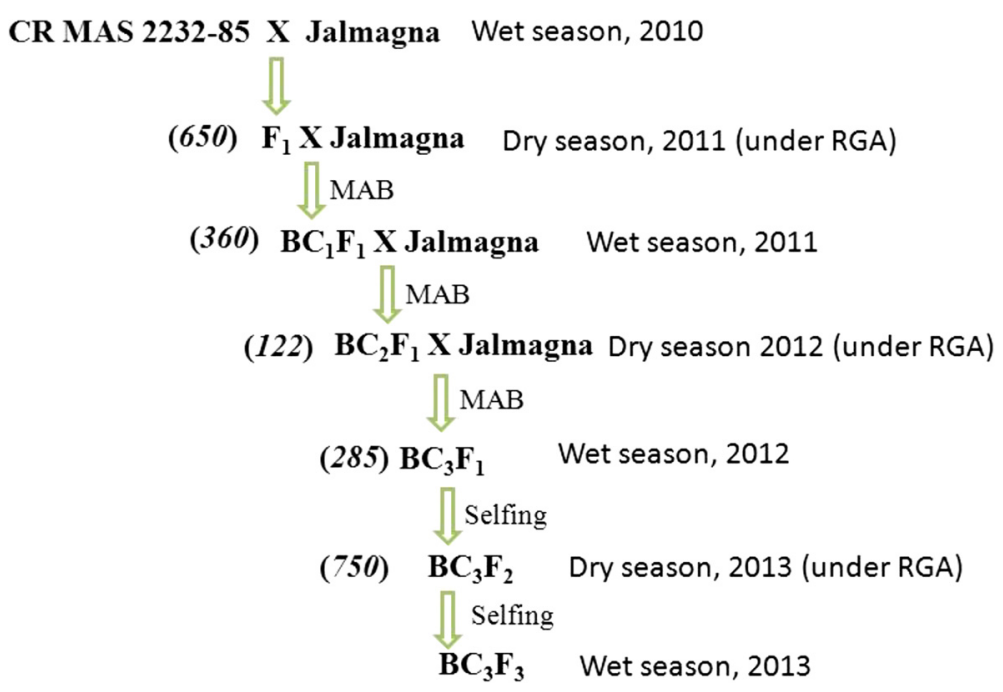

Figure $\mathbf{6}$ Schematic diagram for Pyramiding bacterial blight resistance genes into variety, Jalmagna through MAS (Figures in parentheses indicate the number of hybrids/ lines raised in that generation). 
grains/panicle, 1000 -grain weight, flag leaf, $2^{\text {nd }}$ leaf length and breadth while days to $50 \%$ flowering was recorded on whole plot basis data analysis was performed using SAS statistical software (SAS Institute Inc. 2010).

\section{DNA isolation and PCR amplification}

Mini scale DNA isolation for PCR analysis was carried out as per Dellaporta et al. (1983). The PCR reaction mixture contained $50 \mathrm{ng}$ templates DNA, 5 pico mole of each of the primers, $200 \mu \mathrm{M}$ dNTPs, $1 \mathrm{X}$ PCR buffer (10 mM Tris-HCl, pH 8.3, $50 \mathrm{mM} \mathrm{KCl,} 1.5 \mathrm{mM} \mathrm{MgCl} 2$, and $0.01 \mathrm{mg} / \mathrm{ml}$ gelatin) and 0.6 unit of Taq DNA polymerase in a volume of $20 \mu \mathrm{l}$ and amplification of target sequences were as per earlier reports (Table 1). The PCR products of STS marker RG 136 were digested with restriction enzymes Hinfl as per manufacturer's instructions. The PCR products and the DNA fragments produced by restriction digestions were separated by gel electrophoresis and gel images were analyzed on gel documentation system (SynGene).

\section{Marker analysis}

The primers employed for the three target genes were all from published reports (Table 1). Of the 236 SSRs markers used for parental polymorphism survey, 120 were found to be polymorphic between the parents (range 4-6 per chromosome) and 60 were used for background selection. Data were analyzed and similarity matrix was constructed from binary data with Jaccard's coefficients and dendrogram was generated with unweighted pair group method arithmatic average (UPGMA) algorithm, using FreeTree software (Hampl et al. 2001; Pavalíce et al. 1999) and the dendrograms were visualized by Treeview 32 software (Page 1996). Graphical Geno Types (GGT) Version 2.0 (Van Berloo 1999) software programme was used for the assessment of the genomic contribution of the parent in the selected recombinants based on SSR marker data.

\section{Competing interests}

We declare that the funding agencies and organizations are acknowledged and there is no financial or non financial competing interests.

\section{Authors' contributions \\ SKP conceived the study and participated in its design and coordination and helped to draft the manuscript. DKN and SM carried out the phenotyping and molecular experiments. LB was involved in designing and analysis of the molecular experiments. SRB and AA carried out the crossing work and statistical analysis. EP carried out the analysis and interpretation of data and contributed for preparation of manuscript. SL carried out the bioassays. All authors read and approved the final manuscript.}

\section{Authors' information}

Crop Improvement Division, Central Rice Research Institute, Cuttack, Odisha, 753006, India.

\section{Acknowledgments}

The authors are highly grateful to the Director, Central Rice Research Institute, and Head, Crop Improvement Division, Central Rice Research
Institute Cuttack for providing all the necessary facilities. The work was supported by a grant from Department of Biotechnology, Govt. of India.

Received: 16 October 2014 Accepted: 7 April 2015

Published online: 31 May 2015

\section{References}

Amante-Bordeos A, Sitch L, Nelson R, Dalmacio R, Oliva N, Aswidinnoor H, Leung $H$ (1992) Transfer of bacterial blight and blast resistance from the tetraploid wild rice Oryza minuta to cultivated rice, Oryza sativa. Theor Appl Genet 84:345-354

Bharatkumar S, Paulraj RSD, Brindha PV, Kavitha S, Gnanamanickam SS (2008) Improvent of bacterial blight resistance in rice cultivars ajayothi and IR50 via marker-assisted backcross breeding. J Crop Improve 21:101-116

Bhasin H, Bhatia D, Raghuvanshi S, Lore SJ, Gurpreet K, Sahi KG, Kaur B, Vikal Y, Singh K (2012) New PCR-based sequence-tagged site marker for bacterial blight resistance gene Xa38 of rice. Mol Breeding 30:607-611

Chu Z, Fu B, Yang H, Xu C, Li Z, Sanchez A, Park YJ, Bennetzen JL, Zhang Q, Wang S (2006a) Targeting xa13, a recessive gene for bacterial blight resistance in rice. Theor Appl Genet 112:455-461

Chu Z, Yuan M, Yao J, Ge X, Yuan B, Xu C, Li X, Fu B, Li Z, Bennetzen JL (2006b) Promoter mutations of an essential gene for pollen development result in disease resistance in rice. Genes Dev 20, 1250-1255

Dellaporta SL, Wood J, Hicks JB (1983) A plant DNA minipreparation: version II. Plant Mol Biol Rep 1:19-21

Devadath S (1989) Chemical control of bacterial blight of rice. In: IRRI (ed) Bacterial blight of rice. IRRI, Manila, Philippines, pp 89-98

Dokku P, Das KM, Rao GJN (2013) Pyramiding of four resistance genes of bacterial blight in Tapaswini, an elite rice cultivar, through marker-assisted selection. Euphytica 192:87-96

Gu K, Yang B, Tian D, Wu L, Wang D, Sreekala C et al (2005) R gene expression induced by a type-III effector triggers disease resistance in rice. Nature 435:1122-1125

Gu K, Sangha JS, Li Y, Yin Z (2008) High resolution genetic mapping of bacterial blight resistance gene Xa10. Theor Appl Genet 116:155-163

Hampl V, Pavlicek A, Flegr J (2001) Construction and bootstrap analysis of DNA fingerprinting based phylogenetic trees with the freeware program FreeTree: application to trichomonad parasites. Intl J Syst Evol Microbiol 51:731-735

Hu KM, Qiu DY, Shen XL, Li XH, Wang SP (2008) Isolation and Manipulation of Quantitative trait Loci for Disease Resistance in Rice Using a Candidate Gene Approach. Mol Plant 1(5):786-793

Huang N, Angeles ER, Domingo J, Magpantay G, Singh S, Zhang G, Kumaravadevil N, Bennett J, Khush GS (1997) Pyramiding of bacterial blight resistance genes in rice: marker assisted selection using RFLP and PCR. Theor Appl Genet 95:313-320

lyer AS, McCouch SR (2004) The rice bacterial blight resistance gene xa5 encodes a novel form of disease resistance. Mol Plant Microbe Interact 17:1348-1354

Jena KK, Mackill DJ (2008) Molecular markers and their use in marker-assisted selection in rice. Crop Sci 48:1266-1276

Joseph M, Gopalakrishnan S, Sharma RK (2004) Combining bacterial blight resistance and basmati quality characteristics by phenotypic and molecular marker assisted selection in rice. Mol Breed 13:377-387

Kauffman HE, Reddy APK, Hsien SPY, Merca SD (1973) An improved technique for evaluating resistance of rice varieties to Xanthomonas oryzae. Plant Dis Report 57:537-541

Khush GS (2005) What it will take to feed 5.0 billion rice consumers in 2030. Plant Mol Biol 59:1-6

Khush GS, Mackill DJ, Sidhu GS (1989) Breeding rice for resistance to bacterial leaf blight. In: IRRI (ed) Bacterial blight of rice. IRRI, Manila, Philippines, pp 207-217

Mew TW, Vera Cruz CM, Medalla ES (1992) Changes in the race frequency of Xanthomonas oryza pv. oryzae in response to the planting of rice cultivars in the Philippines. Plant Dis 76:1029-1032

Page RD (1996) TreeView: an application to display phylogenetic trees on personal computers. Comput Appl Biosci 12:357-358

Pavalíce A, Hrda S, Flegr J (1999) Free Tree-freeware program for construction of phylogenetic trees on the basis of distance data and bootstrap/jackknife analysis of the tree robustness, Application in the RAPD analysis of genus Frenkelia. Folia Biol (Praha) 45:97-99

Perez LM, Redona ED, Mendioro MS, Vera Cruz CM, Leung H (2008) Introgression of $\mathrm{Xa4}, \mathrm{Xa}$ and $\mathrm{Xa} 21$ for resistance to bacterial blight in thermosensitive 
genetic male sterile rice (Oryza sativa L.) for the development of two-line hybrids. Euphytica 164:627-636

Pha PN, Lang NT (2004) Marker assisted selection in rice breeding for bacterial leaf blight. Omonrice 12:19-26

Rajpurohit D, Kumar R, Kumar M, Paul P, Awasthi AA, Basha PO, Puri A, Jhang T, Singh K, Dhaliwal HS (2011) Pyramiding of two bacterial blight resistance and a semi dwarfing gene in Type 3 Basmati using marker-assisted selection. Euphytica 178:111-126

Rao KK, Lakshminarasu M, Jena KK (2002) DNA markers and marker-assisted breeding for durable resistance to bacterial blight of rice. Biotechnol Adv 20:33-47

Sanchez AC, Brar DS, Huang N, Khush GS (2000) Sequence tagged site markersassisted selection for three bacterial blight resistance genes in rice. Crop Sci 40:792-797

SAS Institute Inc. (2010) SAS • 9.2 Language Reference: Concepts, Second edn SAS Institute Inc. USA, Cary, NC, p 626 978-1-60764-449-1

Shanti ML, George MLC, Vera Cruz CM, Bernardo MA, Nelson RJ, Leung H, Reddy $J N$, Sridhar R (2001) Identification of resistance genes effective against bacterial leaf blight pathogen in eastern India. Plant Dis 85:506-512

Singh GP, Srivastava MK, Singh RM, Singh RV (1977) Variation in quantitative and Xanthomonas oryzae. Plant Dis Rep 57:537-541

Singh S, Sidhu JS, Huang N, Vikal Y, Li Z, Brar DS, Dhaliwal HS, Khush GS (2001) Pyramiding three bacterial blight resistance genes (xa-5, xa-13 and Xa-21) using marker-assisted selection into indica rice cultivar PR-106. Theor Appl Genet 102:1011-1015

Song WY, Wang GL, Chen LL, Kim HS, Pi LY, Holsten T, Gardner J, Wang B, Zhai WX, Zhu LH, Fauquet C, Ronald PC (1995) A receptor kinase-like protein encoded by the rice disease resistance gene, Xa21. Science 270:1804-1806

Sonti RV (1998) Bacterial leaf blight of rice: new insights from molecular genetics. Curr Sci 74:206-212

Sridhar R, Reddy JN, Singh UD, Agrawal PK (1999) Usefulness of combinations of bacterial blight resistance genes at Cuttack, Orissa, India. IRRN 24(2):24-25

Suh JP, Jeung JU, Noh TH, Cho YC, Park SH, Park HS, Shin MS, Kim CK, Jena KK (2013) Development of breeding lines with three pyramided resistance genes that confer broad-spectrum bacterial blight resistance and their molecular analysis in rice. Rice 6:5

Sundaram RM, Vishnupriya MR, Biradar SK, Laha GS, Reddy GA, Rani NS, Sarma NP, Sonti RV (2008) Marker assisted introgression of bacterial blight resistance in Samba Mahsuri, an elite indica rice variety. Euphytica 160:411-422

Sundaram RM, Laha GS, Viraktamath BC, Sujatha K, Natarajkumar P, Hari Y, Srinivasa Rao K, Reddy CS, Balachandran SM, Madhav MS, Hajira SK, Rani NS, Vishnupriya MR, Sonti RV (2011) Marker Assisted Breeding For Development Of Bacterial Blight Resistant Rice. In: Muralidharan K, Siddiq EA (eds) Genomics and Crop Improvement: Relevance and Reservations, Institute of Biotechnology, Acharya NG Ranga Agricultural University, Hyderabad 500030 India., pp 154-182

Sundaram RM, Chatterjee S, Oliva R, Laha GS, Cruz LE, Sonti RV (2014) Update on Bacterial Blight of Rice: Fourth International Conference on Bacterial Blight. Rice 7:12. doi:10.1186/s12284-014-0012-7

Van Berloo R (1999) GGT: software for display of graphical genotypes. J Hered 90:328-330

Yang S H (2006) Rice varieties registered at national level in 2005. Hybrid Rice 21(6): 25-30. (in Chinese).

Yoshimura S, Yoshimura A, Iwata N, McCouch SR, Abenes SL, Baraoidan MR, Mew TW, Nelson RJ (1995) Tagging and combining bacterial blight resistance genes in rice using RAPD and RFLP markers. Mol Breed 1(4):375-387

Yoshimura S, Yamanouchi U, Katayose Y, Toki S, Wang ZX, Kono I, Kurata N, Yano M, Iwata N, Sasaki T (1998) Expression of Xa-1, a bacterial blight resistance gene in rice, is induced by bacterial inoculation. Proc Natl Acad Sci U S A 95:1633-1668

Submit your manuscript to a SpringerOpen ${ }^{\odot}$ journal and benefit from:

- Convenient online submission

- Rigorous peer review

- Immediate publication on acceptance

- Open access: articles freely available online

- High visibility within the field

- Retaining the copyright to your article

Submit your next manuscript at $>$ springeropen.com 